\title{
レーザ誘起圧力波法によるサブミクロン分解能を持つ 空間電荷測定装置
}

\author{
学生員 武藤 哲* 学生員 市川 英樹* 正 員 田中 康寛* \\ 正員高田 達雄* 正員 前野 恭**
}

\section{Space Charge Measurement Equipment Which Has Sub-micron Resolution by Laser Induced Pressure Pulse Method}

Satoshi Muto*, Student Member, Hideki Ichikawa*, Student Member, Yasuhiro Tanaka*, Member,

Tatsuo Takada*, Member, Takashi Maeno**, Member

The laser induced pressure pulse (LIPP) method has the advantage of higher resolution in the depth direction than other methods. However, in this method, it is demerits that induction noise in laser system is large and measurement signal is low reliability. Therefore, we have developed a new LIPP measurement system using pulse laser of low-density energy, shield technique and deconvolution processing. This system can observe the space charge profile with high reliability. Furthermore, we introduce the new LIPP system, which has sub-micron resolution of 0.6 microns.

キーワード : 空間電荷, レーザ誘起圧力波法, 誘導ノイズ, デコンボリューション

Keywords : space charge, laser induced pressure pulse method, induction noise, deconvolution

\section{1. はじめに}

固体誘電体中の空間電荷分布を測定する方法として主な ものに、パルス静電応力 (Pulsed Electroacoustic : PEA) 法(1)、圧電素子誘起圧力波 (Piezoelectric Induced Pressure Wave Propagation : PIPWP) 法、レーザ誘起圧力波（Laser Induced Pressure Pulse : LIPP) 法などがある。その中で も本研究室で開発された PEA 法は測定が容易で電気的雑音 に強いという特徵があり、最も広く用いられている手法で あるが、薄い絶縁材料を測定する上で問題となるものが試 料厚さ方向への位置分解能である。空間電荷分布を測定す る場合に、測定試料厚さの $5 \%$ 程度を位置分解能の目安とす れば、一般的な PEA 法の位置分解能は $10 \mu \mathrm{m}$ 程度であるた め、厚さ $200 \mu \mathrm{m}$ 以下の薄い絶縁材料の空間電荷分布測定で は分解能の不足を招く。それに対し LIPP 法は、他の測定法 と比較して試料厚さ方向への位置分解能が最も優れる $(1 \mu \mathrm{m}$ 程度) という特徵がある。しかし、高出力 $(\sim 1 \mathrm{~J})$ の

\footnotetext{
* 武蔵工業大学 機械工学システム科 電子計測研究室 干158-8557 東京都世田谷区玉堤 1-28-1 Musashi Institute of Technology, Electronic Measurement Lab. 1-28-1, Tamazutsumi, Setagaya, Tokyo 158-8557

**通信総合研究所 電磁波計測部門 ライダーグループ 干 184-8795 東京都小金井市貫井北町 4-2-1 Communications Research Laboratory 4-2-1 Nukuikita, Koganei, Tokyo 184-8795
}

レーザを用いているため、測定レーザの繰り返し周波数が 最大でも数 $\mathrm{kHz}$ 程度しか得られず過渡的な測定は困難であ る。またレーザをターゲットに当てた際、試料に蒸着した 電極部にもダメージがあるため、同じ試料で何回も測定で きないなどの問題もある。その他にはレーザ装置からの誘 導ノイズが大きいことや測定結果の再現性が良くないこと が挙げられる(2)。そのため我々は PEA 法で用いているノイ ズ遮断シールド技術と、デコンボリューションなどの信号 処理技術をLIPP 法に適用し、板状の下部電極をターゲット として用いることで再現性の優れた出力信号を得ることの できる空間電荷分布測定装置を開発した。また、位置分解 能を最大限に高めて、サブミクロン分解能の空間電荷分布 測定に成功したので報告する。

\section{LIPP 法の原理}

空間電荷分布の測定法の 1 つである LIPP 法の原理を述 ベる。図 1 にLIPP 法の原理図を示す。シート状の試料（絶 縁体）を電極で挟み前面電極表面のターゲットにレーザパ ルスを照射するとターゲットの表面が瞬時に蒸発、膨張す る。このとき生成される圧力波が前面電極を伝搬して試料 に到達する。圧力波が試料を通過する際、試料は厚さ方向 に微小変位するため、内部の電荷も微小変位し試料両側の 


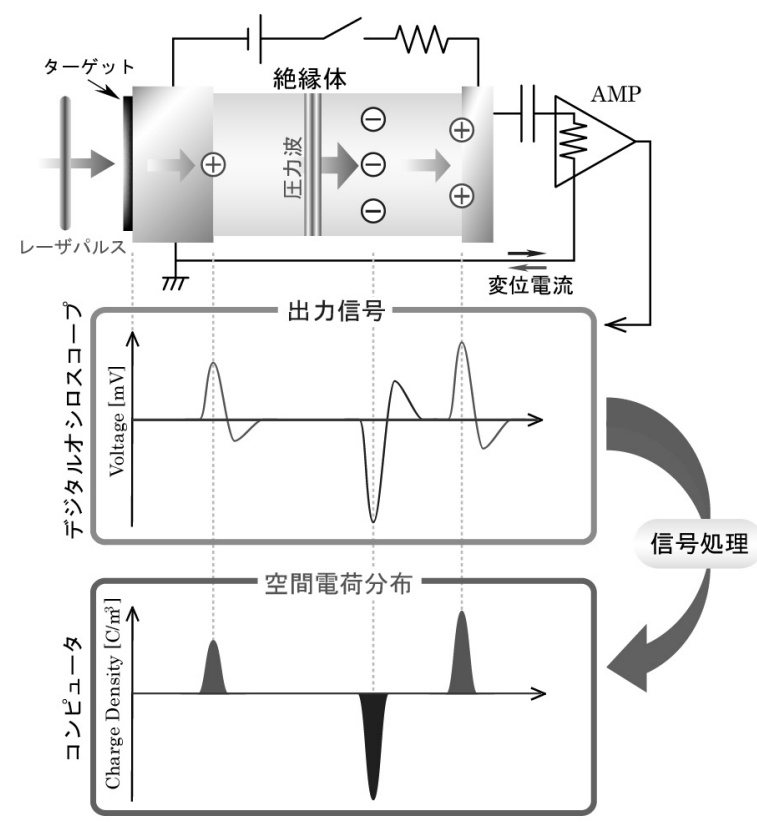

図 1 LIPP 法の原理

Fig. 1. Principle of LIPP method.

電極を結んだ回路に誘導電流を発生させる。このとき圧力 波は試料内の位置（厚さ方向）によって到達する時間が異 なるために、電流波形は電荷の蓄積している位置の情報を 含んだ信号として検出される。得られた電流をアンプで増 幅して、電圧信号としてコンピュータに取り込んだのち、 信号波形を補正するためのデコンボリューション処理、電 圧信号を電荷量に変換するためのキャリブレーション処理 などを行って空間電荷分布を得る。

\section{LIPP 測定装置}

前述の様に LIPP 法は再現性がそしく、誘導ノイズが大き いという久点がある。そこで、我々はこれらの欠点を対処 した測定装置を開発して、信頼性の高い電荷分布の測定を 行った。圧力波発生の再現性はターゲット材料の蒸発を無 くすことで向上させることができる。強力なレーザを照射 してターゲット材料を蒸発させると、蒸発量や照射面の変 化により各圧力波の大きさと形状が変化してしまう。本論 文の LIPP 法では YAG レーザから出射したパルスレーザ (100ps，30mJ，30Hz)をビームエクスパンダで広げること によりエネルギー密度を下げる(約 1/60) ことで、ターゲッ ト材料の蒸発を無くした。次に、パルスレーザのエネルギ 一を圧力波に変換するために、グラファイトスプレーをア ルミ電極に非常に薄く塗布した。塗膜は目視できないほど 薄く、1 $1 \mu \mathrm{m}$ 以下と思われる。圧力波の下部電極内での減 衰を極力抑えるために、電極の厚さ（ターゲット部のみ）を $1 \mathrm{~mm}$ と薄くしている。図 2 に LIPP 法による空閒電荷分布 測定装置の概略図を示す。誘導ノイズに対してはシールド を厳重に施し、更に、高電圧電源・アンプ電源の供給ケー ブルにはノイズフィルタとして $\pi$ 型 LPF を設置して誘導ノ

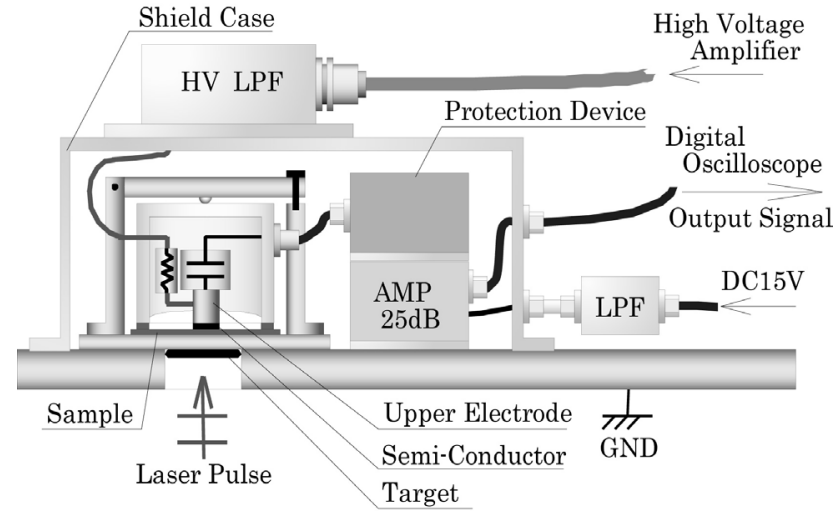

図 2 LIPP 法による空間電荷分布測定装置

Fig. 2. Space charge distribution measurement equipment by LIPP Method.

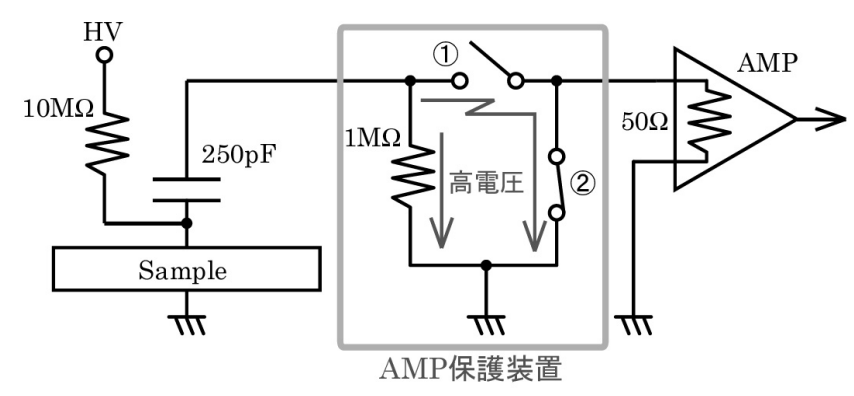

困 3 アンプ保護装置 (非測定時)

Fig. 3. Amplifier protection device (unmeasurement).

イズを減衰した後にシールド内部へ電力供給を行ってい る。また、LIPP 法を含む圧力波法は試料が信号検出部と直 接接続しているため、試料に高電圧を印加する際にアンプ と高電圧電源をコンデンサのみで介していることになり、 アンプを壊しやすい。そこで、コンデンサとアンプの間に アンプ保護装置を挿入している。図 3 にアンプ保護装置の 回路図を示す。

図の(1)、(2)がリードリレーであり、測定時には(1)を ON にして(2)を OFFにし、非測定時にそれぞれ逆にする。これ により測定時の信号はアンプに入力されて増幅して出力さ れる。逆に非測定時には絶縁破壊や沿面放電が発生しても その時のサージ電流は $1 \mathrm{M} \Omega$ の抵抗を通りグランドに落ち る。もし高電圧が(1)のリレーを飛び越えても(2)を通りグラ ンドに落ちる。この 2 重の安全装置によりアンプを保護し ている。また、リードリレーのスイッチングを通常のよう なコイル電流により行うと、シールドシールドケースの外 部よりケーブルを引き込まなければならず、これがノイズ 侵入経路となる。これを防ぐため、リードリレーが入って いる黄銅製のシールドケース外壁に永久磁石を接近させリ レーを磁気的に駆動するようなスイッチング方法によりこ の問題を克服した。この保護回路により、測定する前には 
絶縁破壊や沿面放電が発生しても、これらが発生しない条 件に設定してから測定を行うことでアンプを保護できる。 しかし、絶縁破壊においては印加する高電圧が一定でも時 間が経過することによって発生することがあり、それが測 定中であればアンプを破壊してしまうため注意が必要であ る。

この装置を用いた電荷分布の測定手順は、試料を上部電 極ユニットと下部電極の間に挟んで固定し、シールドケー スを被せる。必要とあればアンプ保護装置を非測定時に設 定して高電圧を試料に印加する。絶縁破壊、沿面放電など の問題が無ければ保護装置を測定時の設定に戻してパルス レーザをターゲットに照射すると測定信号が得られる。

\section{4. 測定システム}

図 4 に空間電荷分布測定システムの概略図を示す。

本システムは LIPP 装置、増幅器（信号帯域幅 $1 \mathrm{GHz}$ 、 $25 \mathrm{~dB})$ に加えて、高電圧電源、 $\mathrm{Nd}$ : YAG モードロックレ ーザ、トリガー検出装置、デジタルオシロスコープ（信号 帯域幅 $1 \mathrm{GHz} 、 8 \mathrm{Gs} / \mathrm{s}$ )、ビームエクスパンダ、 $\mathrm{DC} 15 \mathrm{~V}$ 電源、 コンピュータから構成されている。レーザ装置から $30 \mathrm{~Hz}$ で出射されるパルス幅 $100 \mathrm{ps}$ のパルスレーザ (ビーム直径

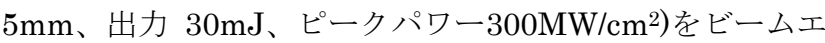
クスパンダで直径を $15 \mathrm{~mm}$ に広げ、パワー密度を $1 / 10$ に低 くしてターゲットに照射させることで焦げ付き（蒸発）を 防いでいる。測定時はフォトダイオードを用いたトリガー 検出装置でパルスレーザとの同期を取り、デジタルオシロ スコープで毎秒 30 回の加算平均を 1000〜5000 回行って測 定波形を得る。その後コンピュータに測定波形を取り込み、 デコンボリューション等の信号処理を施して空間電荷分布 を得る。(1)

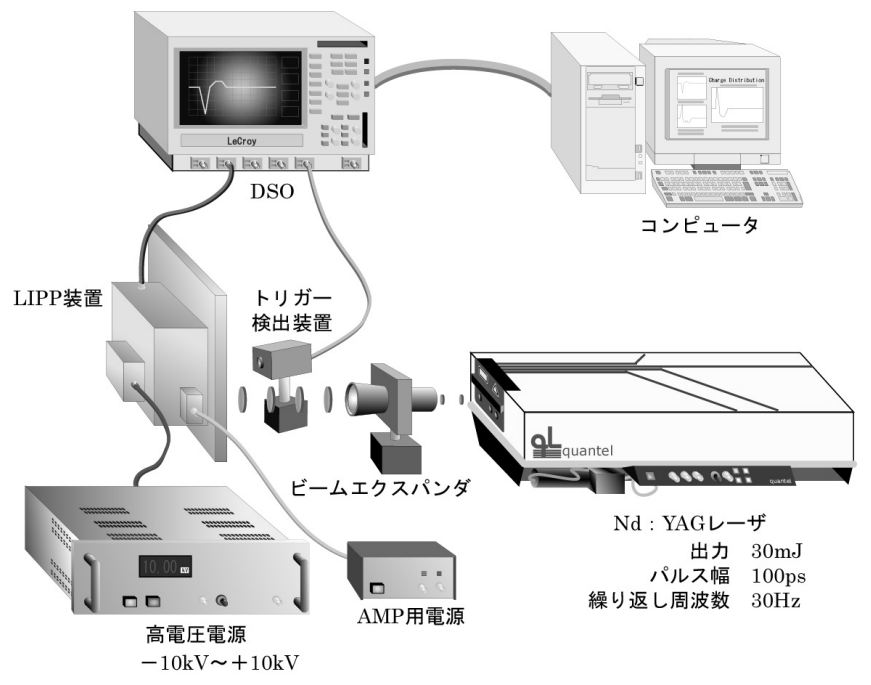

図 4 LIPP 法による空間電荷分布測定システム

Fig. 4. Space charge distribution measurement system by LIPP Method.

\section{5. 測定例}

本システムを用いて電荷の蓄積している試料について空 間電荷分布測定を行った。界面をコロナ帯電させた 2 枚の PET $(100 \mu \mathrm{m})$ を用いたサンドイッチ状試料の空間電荷分 布を図 5 に示す。（a）は測定した電圧波形であり、試料に 電圧を印加せずに 5000 回の加算平均を行った結果である。 （b）は測定波形に信号処理を施した後の空間電荷分布であ る。この電荷分布を見ると、2 枚の PET の間に表面帯電し た正の電荷が存在し、この電荷によって両電極界面に負の 電荷が誘導されていることがわかる。なお、この結果の位 置分解能（界面電荷により生じるインパルスの半值幅）は $3.2 \mu \mathrm{m}$ である。

強力なレーザを用いた従来の LIPP 法では信号処理が不 要とされていたが、波形歪みは必ず存在し、更に歪みの形 状も測定毎に異なる場合があり、再現性の高い電荷分布測 定を行うことは困難であった。それに対して、本 LIPP シス テムでは低エネルギー密度のレーザを繰り返しターゲット に照射して加算平均を行うことで、再現性の高い測定波形 を得ることが可能である。そのため、何度測定を行っても

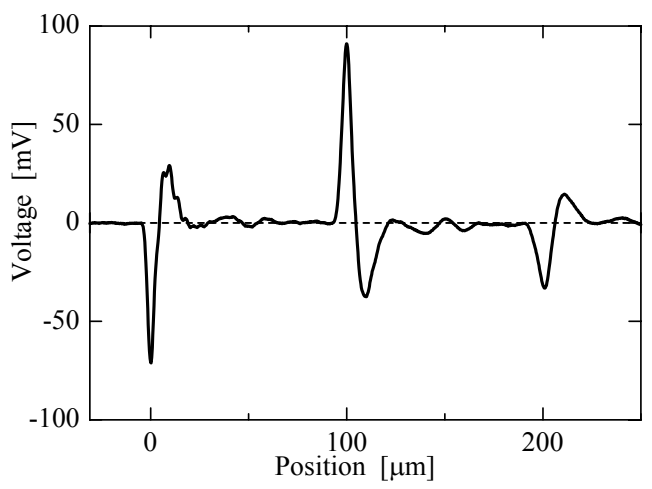

(a) 測定波形

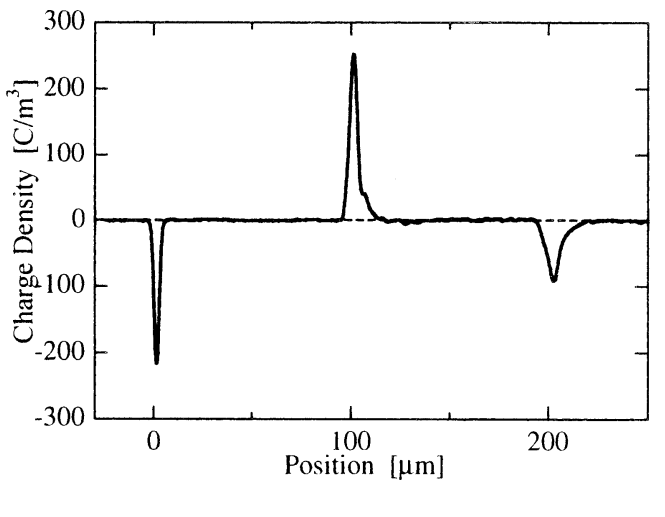

（b）空間電荷分布

図 5 PET $(100 \mu \mathrm{m}) 2$ 枚の空間電荷分布

Fig. 5. Space Charge Distribution in sandwich PET. 
波形歪みが一定であり、デコンボリューション処理によっ て PEA 法と同様に信頼性の高い空間電荷分布測定が可能と なった。

次に、高位置分解能の有用性を示すために、非常に薄い 絶縁体の電荷分布測定結果を紹介する。PET $(30 \mu \mathrm{m})$ に DC $8 \mathrm{kV}$ を $1 \mathrm{~h}$ 印加した後、短絡状態を保持して $0 \mathrm{~h}, 1 \mathrm{~h}, 2 \mathrm{~h}$ 後の空間電荷分布を測定した結果を図 6 に示す。（a）は PEA 法（分解能 $12 \mu \mathrm{m}$ 程度）を用いて測定した結果であり、 (b) は LIPP 法を用いた結果である。

試料は 1 枚の PET $(30 \mu \mathrm{m})$ シートから切り出したもので あるため、両測定において試料、測定条件は同一といえる。 （a）を見ると、DC $8 \mathrm{kV}$ 印加時に試料内部に負の電荷がほぼ 一様に帯電し、短絡後の時間経過に伴って試料内部の負電 荷が減少していくように見える。それに対して、（b）では 短絡直後における試料内部の負電荷は両電極付近に集中し ており、短絡後は陽極付近の負電荷は減少が少なく、陰極 付近の負電荷が著しく減少している様子がわかる。また、 短絡直後の陰極付近の負電荷は電極界面から約 $5 \mu \mathrm{m}$ 以内に 多く蓄積していたこともわかる。更に、（a）の結果では試 料厚さに対する位置分解能が低すぎるため、試料内部の負 電荷と正の電極誘導電荷が重なる部分が多く、打ち消しあ つてしまうために誘導電荷のピーク位置が実際の試料厚さ よりも広がった結果となっており、ピーク值も測定される

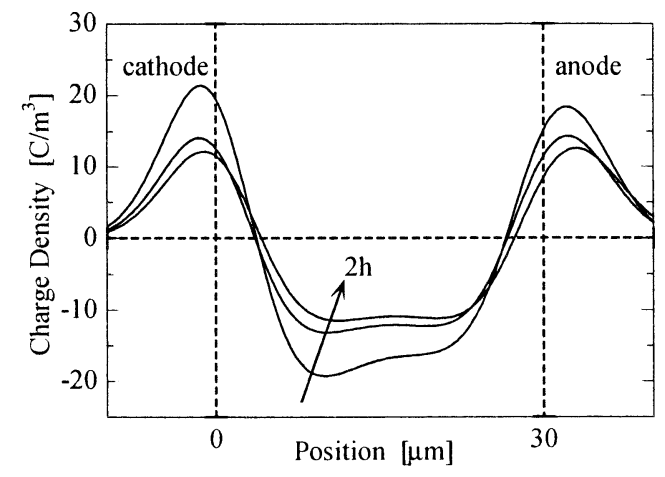

(a) PEA 法

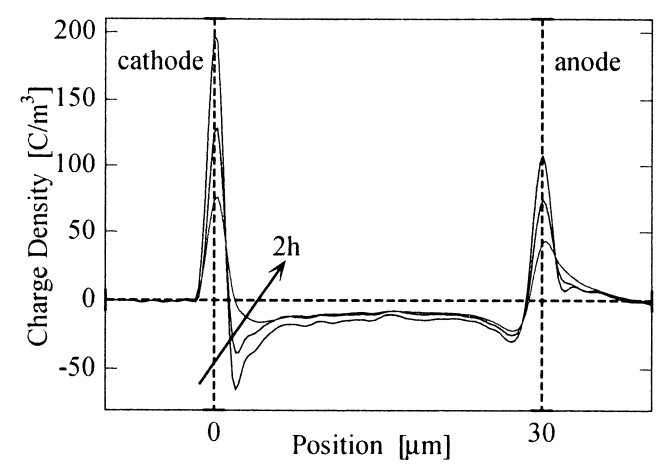

(b) LIPP 法

図 6 PET $(30 \mu \mathrm{m})$ に電圧印加後の電荷分布挙動

Fig. 6. Space charge decaying after dc voltage application in PET.
べき值（電荷密度の計算值）より低くなっている。

このように高位置分解能は非常に薄い試料の電荷分布測 定に有力であり、電荷の挙動が最も著しい電極近傍の電荷 挙動を観察する場合には必須となる。

\section{6. サブミクロン分解能測定}

さらに位置分解能を向上させる事を目的として、装置の 変更を行った。位置分解能を向上させるためには、試料を 伝搬する圧力波の幅を狭くすれば良い。本 LIPP システムで は、パルスレーザの幅は 100ps であり、ターゲットの厚さ も $1 \mu \mathrm{m}$ 以下と考えられるため、ターゲットの音速を $2000 \mathrm{~m} / \mathrm{s}$ とすれば発生する圧力波の幅は $0.5 \mathrm{~ns}$ 程度と見積 もられる。しかし、圧力波は試料に到達する前に下部電極 中を伝搬するため、下部電極内で圧力波の減衰が起こる。 そのため、下部電極の厚さは可能な限り薄いほうが高分解 能測定に適している(3)。

次に、高分解能信号を発生させることができても、その 信号を減衰させることなく測定するためには信号検出系を 広帯域化する必要がある。一般的に、広帯域な信号検出系 （増幅器など）の周波数特性はバターワース型のローパスフ イルタ（LPF）と同等と考えてよい。そこで、非常に幅の狭 いパルス信号がバターワースフィルタを通ることによって パルス幅がどれだけ広がって出力されるかの計算を行っ た。遮断周波数を $10,6,4,3,2,1 \mathrm{GHz}$ と変化させた $\mathrm{LPF} に$ パルス幅 $0.1 \mathrm{~ns}$ の電圧信号を入力したときの出力波形の計 算結果を図 7 に示す。

この結果より、遮断周波数が高いほど出力波形のパルス 幅が狭いことは明白である。また、インパルス波形を LPF に通したときの、LPF の遮断周波数と出力波形のパルス幅 の関係を図 8 に示す。計算結果のグラフは傾き-1 の直線上 にあり、遮断周波数とパルス幅が反比例の関係にあること を示している。この計算結果から遮断周波数 fc とパルス幅 $\mathrm{Pw}$ は次式の関係にあることがわかった。

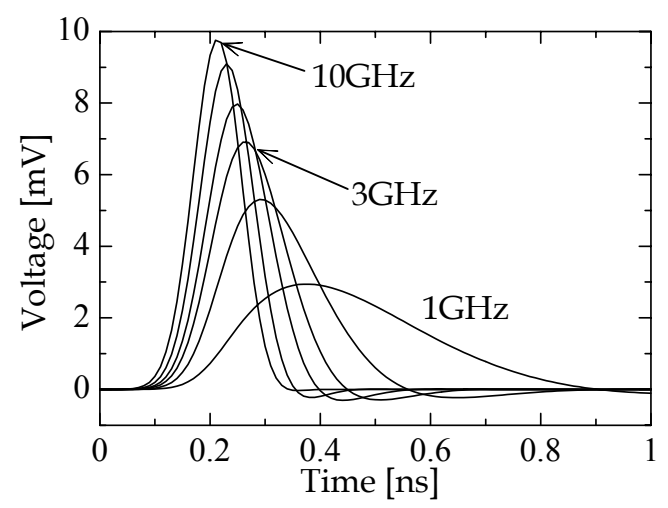

図 7 信号検出系の帯域と出力信号

Fig. 7. Band of a signal detection system and output signal. 


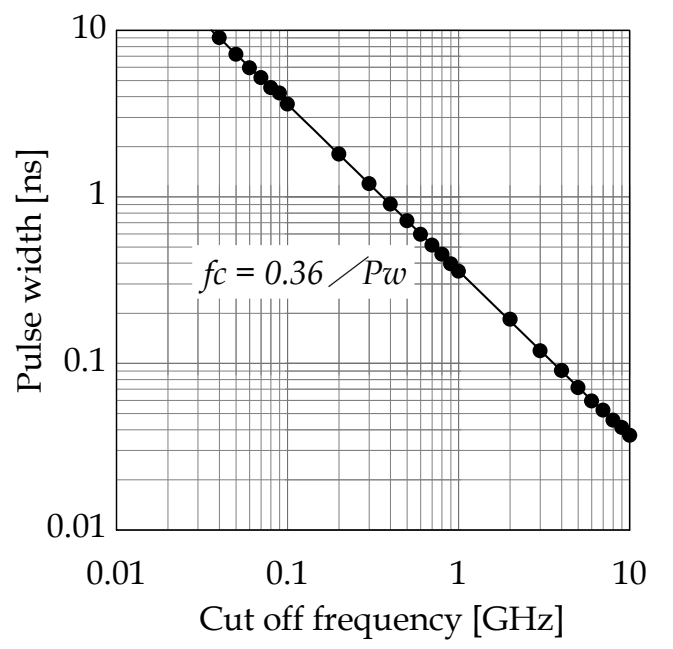

図 8 遮断周波数とパルス幅の関係

Fig. 8. Relation between cut off frequency and pulse width.

$$
P w=0.36 / f c
$$

これは、測定信号の帯域が信号検出系の帯域を上まわる 場合には信号検出系の帯域を向上させることで、位置分解 能も比例して向上することを示している。また、試料中の 音速を $2000 \mathrm{~m} / \mathrm{s}$ とすれば帯域幅 $1 \mathrm{GHz}$ の場合、位置分解能 は $0.72 \mu \mathrm{m}$ となる。これより、サブミクロン分解能を目指す には帯域幅 $1 \mathrm{GHz}$ 以上が必要となる。

以上のことを考慮して、LIPP 装置の高分解能化を行っ た。先に示した LIPP 装置を改良した装置図を図 9 に示す。 下部電極の厚さを以前の $1 \mathrm{~mm}$ から $0.3 \mathrm{~mm}$ に変更した。こ れは下部電極としての機械的強度を保つ限界の厚さであ る。また、アンプ保護装置を通過する事による周波数特性 の悪化を防ぐため、試料とアンプは直結とし、信号線を極 力短くするためにアンプは上部電極ユニットに設置した。 LIPP 法における信号検出系の帯域は主にアンプと DSO で 決定される。これまで用いていたアンプとDSO の帯域は $1 \mathrm{GHz}$ であったが、どちらも帯域 $3 \mathrm{GHz}$ のものに変更して 測定を行った。

高分解能化した LIPP 装置を用いて空間電荷分布測定を 行った結果を図 10 に示す。試料はPET $(30 \mu \mathrm{m})$ に $1 \mathrm{kV}$ を 印加中であり、位置分解能は従来の $3 \mu \mathrm{m}$ 程度から $0.6 \mu \mathrm{m}$ に 向上した。空間電荷分布測定において、目安となる位置分 解能を試料厚さの $5 \%$ とすれば、分解能 $0.6 \mu \mathrm{m}$ の本 LIPP シ ステムでは厚さ $12 \mu \mathrm{m}$ 程度の極薄試料の電荷分布測定が可 能である。

さらなる高分解能化には、より幅の狭い圧力波を試料に 伝搬させなければならないため、さらに薄い下部電極を使 用するなどの困難な課題も多く、現状ではこれ以上の高分 解能化は難しい。

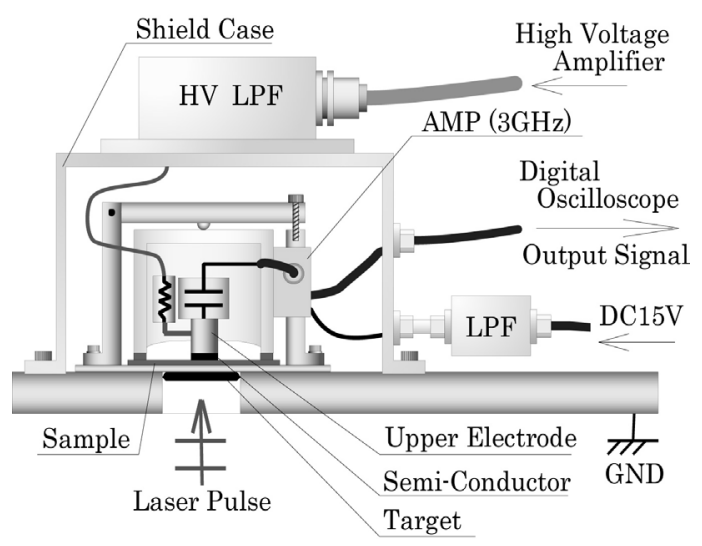

図 9 高分解能化した LIPP 装置

Fig. 9. High resolution LIPP equipment.

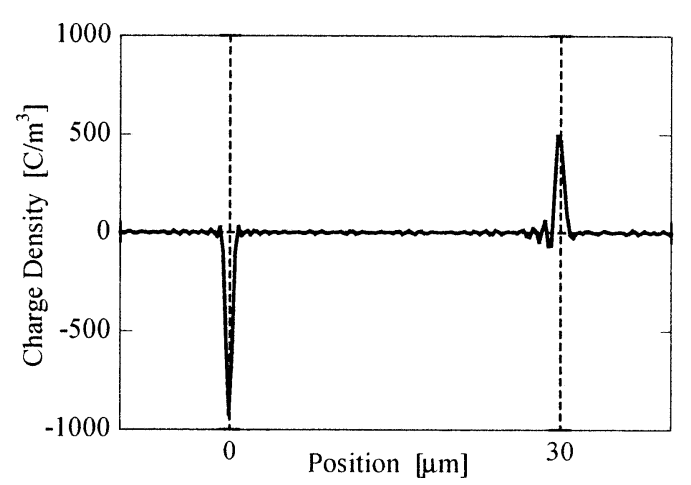

図 10 電圧印加中の PET $(30 \mu \mathrm{m})$ の空間電荷分布

Fig. 10. Space charge distribution in biased PET.

\section{7. むすび}

LIPP 法を用いて、PEA 法と同等の高い再現性をもつ空 間電荷分布測定装置を開発した。位置分解能 $3 \mu \mathrm{m}$ 程度の場 合には保護回路を使用する事で絶縁破壊から装置を守る事 が出来るようになった。さらに、サブミクロンの分解能を 持つ測定装置を開発し、位置分解能 $0.6 \mu \mathrm{m}$ の空間電荷分布 測定を可能とした。しかしながら、現状ではこれ以上の高 分解能化は難しく、保護回路の使用も出来ないため、わず かな絶縁破壊でも装置が破壊するといった問題が残ってい る。

(平成 14 年 1 月 28 日受付, 平成 14 年 6 月 11 日再受付)

\section{文献}

(1) T. Maeno, K. Fukunaga, T. Tanaka, and T. Takada : "Signal Processing of the High-resolution PEA Charge Measurement System", T. IEE Japan, Vol.115-A, No. 5, pp. 405-410 (1995-5) (in Japanese)

前野 恭- 福永 香- 田中康寛・高田達雄 :「高分解能 PEA 空間電 荷測定装置における信号処理」, 電学論 A， 115，5，pp.405-410 (1995-5) 
(2) T. Takada : "Current Trend of Space Charge Measurement Techniques", T. IEE Japan, Vol.117-A, No. 6, pp. 545-551 (1997-6) (in Japanese)

高田達雄：「空間電荷計測技術の最前線」, 電学論 A, 117, 6 , pp.545-551 (1997-6)

(3) T. Miyazaki, T. Tanaka, T. Takada, and T. Maeno : "Improvement in Resolution of PEA Space Charge Measurement System and Measurement of Acoustic Loss in Metal Materials", Trans, IEE Japan, Vol.122-A, No. 1, pp. 107-111 (2002) (in Japanese) 宮崎達也・田中康寛・高田達雄・前野 恭 : 「PEA 空間電荷分布測 定装置の高分解能化と金属中の圧力波減衰の測定」，電学論 $\mathrm{A}, 122$, 1, pp.107-111 (2002-1)

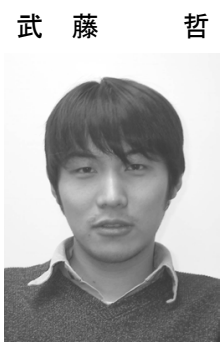

哲（学生員） 1976 年 9 月 8 日生まれ。1999年 3 月武蔵工業大学機械工学科卒業。2002 年 3 月 同大学大学院生産機械工学専攻修士課程修了。 主として誘電体中の空間電荷分布測定に関寸 る研究に従事。2002 年 4 月より横河電機株式 会社勤務。

市 川 英 樹 (学生員) 1978 年 10 月 3 日生まれ。 2001 年 3 月武蔵工業大学機械工学科卒業。現在、同大 学大学院生産機械工学専攻修士課程在学中。主 として誘電体中の空間電荷分布測定に関する 研究に従事。
田 中 康 寛 (正員) 1961 年 9 月 10 日生まれ。 1991 年 3 月早稲田大学大学院理工学研究科博士課程修

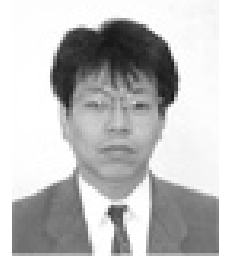
了。1990 年 4 月同大学理工学部助手属任。1992 年 4 月武蔵工業大学機械工学科専任講師, 1998 年 4 月同大学機械システム工学科助教授着任。 工学博士。' 99 年 4 月 - ' 00 年 3 月英国サザン プトン大学客員研究員。主として有機高分子材 料の高電界特性, 特に空間電荷分布測定の研究 に従事。1990 年電気学会論文発表賞受賞。IEEE 会員。

高 田達 雄 （正員） 1939 年 8 月 8 日生まれ。1963 年 3 月

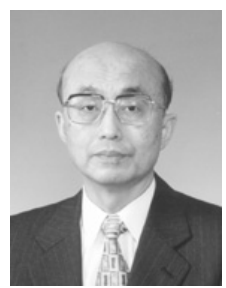
武蔵工業大学電気工学科卒業。1966 年 3 月東 北大学大学院工学研究科電気及び通信工学専 攻修士課程修了。1967 年 4 月武蔵工業大学講 師，1974 年同助教授，1986 年同教授，現在に 至る。工学博士。1981 年 83 年米国 MIT 客 員研究員。主として高分子誘電体中の帯電現象 と空間電荷分布測定技術の研究に従事。1974, 81,90 年電気学会論文賞受賞。1996 年電気学会進歩賞受賞。1997 年静電気学会進歩賞受賞。IEEE Fellow。

前 野 恭 (正員) 1957 年 8 月 28 日生まれ。 1989 年 3 月武蔵工業大学大学院工学研究科電気工学専 攻博士課程修了。現在、通信総合研究所電磁波 計測部門ライダーグループ所属。工学博士。主 として誘電体中の空間電荷分布、電界分布の計 測およびレーザー応用研究に従事。1990 年電 気学会論文賞、1996 年電気学会進歩賞、1997 年静電気学会進歩賞受賞。1999 年より武蔵工 業大学機械システム工学科客員助教授。 